\title{
Isolation and Functional Characterization of Human
}

\section{Intestinal Mucosal Lymphoid Cells}

\author{
David M. Bull and Michael A. Bookman \\ From the Gastrointestinal Unit and the Thorndike Laboratory of the Harvard Medical School, \\ Departments of Medicine, Beth Israel Hospital, and Harvard Medical School, Boston, Massachusetts \\ 02215
}

\begin{abstract}
A B S T RAC T Viable suspensions of human colonic mucosal lymphoid cells have been prepared by sequential treatment of tissue with dithiothreitol, EDTA in calcium- and magnesium-free salt solutions, and purified collagenase. The intestinal lymphocyte population, in comparison with that of peripheral blood, had greater numbers of bone marrow-derived cells, particularly cells bearing membrane IgA; showed spontaneous association with macrophages; underwent rapid rosette formation with sheep erythrocytes; and demonstrated increased in vitro synthesis of immunoglobulin. Total thymus-derived cells were equal in the two populations. Decreases were found in "null" cell numbers, in cells bearing membrane IgD and IgM, and in responsiveness to phytohemagglutinin. Macrophage/monocytes in the intestinal population were increased in size, granularity, motility, sustained glass adherence, and phagocytic activity. Human intestinal lymphoid cells appear to constitute a cell population that is more "mature" and/or "activated", in comparison with the lymphoid cells of peripheral blood. The method of preparation should lend itself to the study of inflammatory bowel disease, gastrointestinal cancer, and the intestinal secretory immune system.
\end{abstract}

\section{INTRODUCTION}

The immune reactivity of circulating lymphocytes and monocytes may not reflect events mediated by lymphoid cells in the tissues; nonetheless, peripheral blood has been used almost exclusively as the source of cells for immunological studies in gastrointestinal cancer, inflammatory bowel disease, and gastrointestinal autoimmunity. Tissue-based immunological responses may be influenced more directly by fixed lymphoid elements rather than those that circulate. To understand the role of these cells in disease states

Received for publication 25 October 1976 and in revised form 3 January 1977.
$(1,2)$, a knowledge of their basic immunological properties is required. This report describes a method for the isolation of viable human intestinal mucosal lymphoid cells and compares their functional immune characteristics with those of circulating lymphocytes and monocytes.

\section{METHODS}

\section{Lymphoid cell isolation}

Isolation of intestinal mucosal lymphoid cells. The procedure for the isolation of intestinal lymphoid cells is depicted in Fig. 1. Colonic tissue was obtained at surgery from three patients with villous adenoma, four with adenocarcinoma, three with diverticulitis, and two with Crohn's disease. All tissues used were from sites at least $10 \mathrm{~cm}$ from areas of disease involvement and were histologically normal in appearance. The specimens, $10-20 \mathrm{~cm}^{2}$ in area, were transported and washed in cold $\left(4^{\circ} \mathrm{C}\right)$ tissue culture medium, RPMI 1640 (Grand Island Biological Co., Grand Island, N. Y.) containing an antibiotic mixture $(100 \mathrm{U} / \mathrm{ml}$ penicillin, $50 \mathrm{U} / \mathrm{ml}$ Fungizone, and $100 \mu \mathrm{g} / \mathrm{ml}$ streptomycin, GIBCO) and $50 \mu \mathrm{g} / \mathrm{ml}$ gentamicin. During preliminary washing, a soft rubber policeman was used to remove debris without damage to the specimen. The mucosa was dissected free of underlying musculature along the fibrous connective tissue layer and all remaining strands of fibrous tissue were carefully removed. After briefly washing the mucosa in calcium- and magnesium-free Hanks' balanced salt solution (CMF-HBSS), ${ }^{1}$ it was cut into smaller $(2 \times 2$ $\mathrm{cm})$ pieces. Incubating these with stirring for $15 \mathrm{~min}$ at $22^{\circ} \mathrm{C}$ in CMF-HBSS containing $1 \mathrm{mM}$ dithiothreitol (DTT) effectively removed adherent mucus. The tissue was again washed in CMF-HBSS and incubated with sitrring at $37^{\circ} \mathrm{C}$ for $90 \mathrm{~min}$ in $100 \mathrm{ml}$ of CMF-HBSS containing $0.75 \mathrm{mM}$ EDTA. The $\mathrm{pH}$ was maintained continuously between 7.2 and 7.4 by addition of $10 \% \mathrm{NaHCO}_{3}$. During this incubation, intact viable epithelial cell crypts were dissociated from the tissue. This step was repeated until crypt epithelium was no longer

${ }^{1}$ Abbreviations used in this paper: CMF-HBSS, calciumand magnesium-free Hanks' balanced salt solution; Con A, concanavalin A; DTT, dithiothreitol; E, erythrocyte; EAC rosettes, cells forming rosettes with antibody and complement; HBSS, Hanks' balanced salt solution; PHA, phytohemagglutinin extract. 
seen in the medium under phase microscopy. The tissue was washed twice in CMF-HBSS and any remaining epithelial cells were removed with a rubber policeman. After preincubation in a complete medium (RPMI 1640) for $20 \mathrm{~min}$, the tissue was incubated with stirring at $37^{\circ} \mathrm{C}$ in a $95 \%$ air- $5 \% \mathrm{CO}_{2}$ atmosphere in RPMI 1640 containing antibiotics, $10 \%$ pooled human blood group AB serum, $0.05 \mathrm{mg} / \mathrm{ml}$ purified collagenase (CLSPA, Worthington Biochemical Corp., Freehold, N. J.) and then adjusted to $\mathrm{pH} 7.2$ with $\mathrm{NaHCO}_{3}$. Incubation was carried out for $18 \mathrm{~h}$, although dissociation of the lamina propria and liberation of lymphoid cells was nearly complete at $6 \mathrm{~h}$. The crude lymphoid cell suspension was washed twice and resuspended; larger pieces of debris were allowed to sediment. Suspended cells were centrifuged over a layer of Ficoll-Hypaque (Pharmacia Fine Chemicals Inc., Piscataway, N.J., Winthrop Laboratories, Evanston, Ill.) (3) to remove red cells and debris. After washing, the cells were resuspended in medium, and used within 3-6 $\mathrm{h}$. If desired, the cells could be maintained in viable condition for at least $72 \mathrm{~h}$ in RPMI 1640 containing antibiotics and $10 \%$ human $\mathrm{AB}$ serum.

Isolation of peripheral blood lymphoid cells. $30 \mathrm{ml}$ of peripheral blood from the surgical patients who had served or were scheduled to serve as donors of intestinal mucosal tissue, or from normal volunteers, were drawn into heparinized test tubes. The blood was diluted with an equal volume of HBSS and centrifuged over a Ficoll-Hypaque layer. Cells accumulating at the Ficoll-dilute plasma interface were used for all subsequent studies. When comparison of the functional properties of intestinal and circulating lymphoid cells was to be made, a suspension of peripheral blood mononuclear cells was subjected to similar chemical treatment to that used in the intestinal cell isolation process.

\section{Lymphoid cell characterization}

Immunofluorescence microscopy. Fluorescein-conjugated specific antibody to the heavy chains of immunoglobulins G, M. A. D., and E, to $\kappa$ - and $\lambda$-immunoglobulin light chains, as well as polyvalent antisera having activity against all of these components, were obtained from Meloy Laboratories Inc. (Springfield, Va.), Behring Diagnostics, American Hoechst Corp. (Somerville, N. J.), and Atlantic Antibody Co. (S. Windham, Maine). Cytophilic immunoglobulin was removed by suspending the cells at a concentration of $3 \times 10^{6} / \mathrm{ml}$ in minimal essential medium and $10 \%$ fetal calf serum (GIBCO), incubating at $37^{\circ} \mathrm{C}$ for $30 \mathrm{~min}$, and then washing at $37^{\circ} \mathrm{C}(4,5)$. Immunofluorescent staining of membrane immunoglobulin and fluorescence microscopy were carried out using a modification of the method of Pernis et al. (6). Cells were suspended at a concentration of 10 $\times 10^{6} / \mathrm{ml}$ in HBSS containing $10 \mathrm{mM}$ sodium azide to prevent cap formation. A $0.2-\mathrm{ml}$ aliquot of cell suspension was incubated for $45 \mathrm{~min}$ at $4^{\circ} \mathrm{C}$ with $20 \mu \mathrm{l}$ of the appropriate fluorescein-conjugated anti-immunoglobulin. After two washes in HBSS, 1 million cells were cytocentrifuged onto a glass slide and fixed with methanol. The nuclei were counterstained with $0.03 \%$ methyl green in $50 \%$ methanol. After rinsing with $50 \%$ methanol, the slides were mounted in phosphate-buffered saline-glycerol (1:9), pH 9, for microscopy. Positive cells were counted as the percentage of the total mononuclear cells.

Antibody synthesis. In each of six capped test tubes, 4 million lymphoid cells were cultured for $48 \mathrm{~h}$ at $37^{\circ} \mathrm{C}$ in $2 \mathrm{ml}$ of amino acid-free minimal essential medium (GIBCO) containing $15 \%$ fetal calf serum, $25 \mathrm{mM}$ Hepes, antibiotics, and $2 \mathrm{uCi}$ of a ${ }^{14} \mathrm{C}$-amino acid mixture (NEC-445, New England Nuclear, Boston, Mass.). The cultures were then centrifuged and each supernate was passed through a 0.45

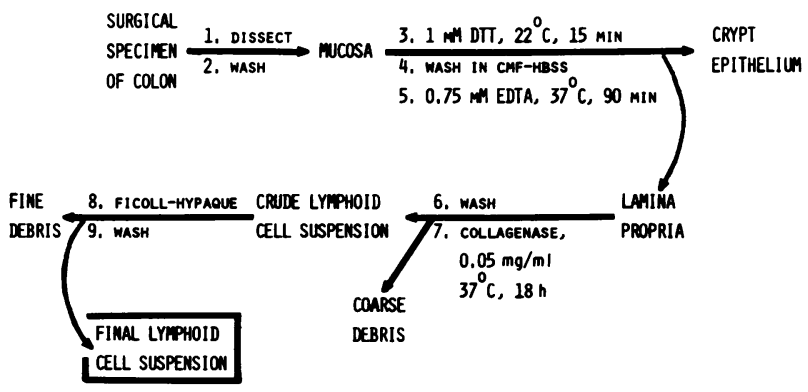

FIGURE 1 Procedure for the isolation of colonic lymphoid cells.

$\mu \mathrm{m}$ filter (Millipore Corp., Bedford, Mass.), and arranged as duplicates for further processing. To one duplicate was added goat polyvalent anti-human immunoglobulin antiserum and rabbit anti-goat immunoglobulin antiserum. Optimal precipitating quantities of each antiserum had been previously determined. To a second supernatant duplicate was added a volume of normal goat serum equal to the amount of goat antiserum previously used, and rabbit anti-goat immunoglobulin as before, to measure background precipitation. To a third duplicate was added goat anti-human IgA and rabbit anti-goat antiserum to selectively precipitate the IgA synthesized. Similar additions of goat and rabbit antiserum were also made to a duplicate containing $2 \mathrm{ml}$ minimal essential medium and radioactive amino acids only (all antisera from Atlantic Antibody Co.). Tubes were incubated for $1 \mathrm{~h}$ at $37^{\circ} \mathrm{C}$ and overnight at $4^{\circ} \mathrm{C}$. Precipitates were spun, washed three times, and then prepared for liquid scintillation counting. Incorporation of radioactive amino acids into immunoglobulin was expressed as the difference between specific and background precipitates.

Lymphoblastic transformation. Mononuclear cells were adjusted to a concentration of $1 \times 10^{6} / \mathrm{ml}$ in TC199 containing $10 \%$ pooled human AB serum and antibiotics. Mitogen concentrations used for stimulation were $0.1 \mathrm{ml} / \mathrm{ml}$ of crude reconstituted phytohemagglutinin extract (PHA, GIBCO) and $0.01 \mathrm{mg} / \mathrm{ml}$ concanavalin A (Con A, Sigma Chemical Co., St. Louis, Mo.). A 0.2-ml aliquot of each suspension $\left(2 \times 10^{5}\right.$ cells) was placed in Microtest wells (Falcon 3040 ) and incubated in $5 \% \mathrm{CO}_{2}-95 \%$ air at $37^{\circ} \mathrm{C}$ for $72 \mathrm{~h}$. $1 \mu \mathrm{Ci}$ of $\left[{ }^{3} \mathrm{H}\right]$ thymidine was added per well and after $18 \mathrm{~h}$ the cells were washed from the wells and prepared for liquid scintillation counting. All tests were conducted in quadruplicate.

Erythrocyte rosetting techniques. The thymus-derived (T) lymphocyte subpopulation was enumerated by the formation of spontaneous rosettes with sheep erythrocytes according to the method of Jondal et al. (7). "Activation" rosettes, those formed immediately upon exposure to sheep erythrocytes, were assessed according to the method of Wybran and Fudenberg (8). Thymus-independent lymphocyte subpopulations, which form rosettes in the presence of antibody and complement (EAC), were enumerated according to the method of Ehlenberger and co-workers (9).

Monocyte/macrophage monolayers. Monolayers of peripheral blood monocytes or mucosal macrophages were prepared by injecting 4-6 $\times 10^{6}$ mononuclear cells inMinimal Essential Medium with $10 \%$ heat-inactivated pooled human AB serum into Sykes-Moore tissue culture chambers (Bellco Glass, Inc., Vineland, N. J.) and allowing the cells to adhere to the base cover slip for a 60 -min period (10). Nonadherent cells were removed by rinsing with fresh medium. These monolayers were maintained in culture in 


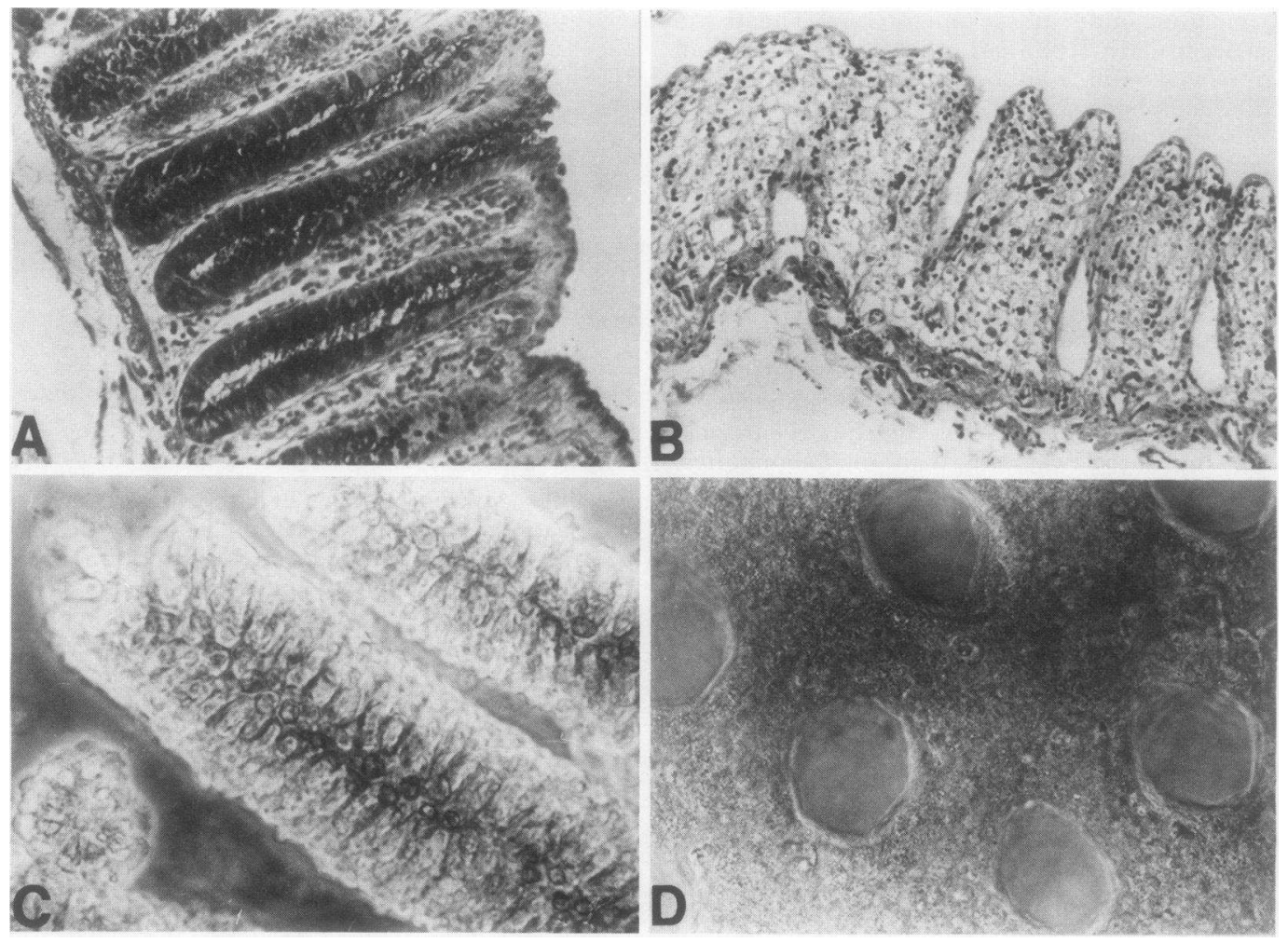

FIGURE 2 Appearance of colonic tissue during the isolation of lymphoid cells. (A) Appearance of colonic mucosa before treatment, showing intact epithelium (Periodic-acid-Schiff-hematoxylin $\times 100$ ). (B) Colonic mucosa as in (A) but devoid of crypt epithelium, after treatment with DTT and EDTA (Periodic-acid-Schiff-hematoxylin $\times 100)$. (C) Colonic crypt epithelium liberated by treatment of colonic mucosa with DTT and EDTA (phase contrast $\times 200$ ). (D) Tangential view of colonic mucosa after treatment with DTT and EDTA, showing void areas from which crypt epithelium has been removed (whole mount; differential interference contrast $\times 150$ ).

an atmosphere of $5 \% \mathrm{CO}_{2}-95 \%$ air at $37^{\circ} \mathrm{C}$. Morphology of the adherent cell populations was observed microscopically at intervals up to 30 days. Phagocytic capacity was assessed by incubating the cells with latex particles $(2 \mu \mathrm{m}$ in diameter, Ernest F. Fullam, Inc., Schenectady, N. Y.) for $1 \mathrm{~h}$, followed by rinsing and examination of the monolayer under phasecontrast microscopy, at which time ingested particles were counted.

\section{RESULTS}

\section{Isolation Procedure}

Results obtained with each type of surgical specimen were similar and are presented together. The histological appearance of a typical intestinal tissue at several points in the isolation procedure is shown in Fig. 2. The starting mucosa (Fig. 2A) was transformed by treatment with DTT and EDTA to a framework of lamina propria devoid of epithelium (Fig. 2B). This resulted in the simultaneous elaboration of intact crypt epithelial structures (Fig. 2C), leaving the lamina propria with "holes" seen in tangential view in Fig. $2 \mathrm{D}$.

\section{Cell yield and viability}

Dissociation of the lamina propria with purified collagenase yielded a crude population of morphologically heterogenous cells (Fig. 3A) which, after sedimentation over Ficoll-Hypaque, was $98 \%$ viable by trypan blue exclusion. These cells were $97 \%$ mononuclear, $3 \%$ polymophonuclear (predominantly eosinophils), and were not contaminated by epithelial cells, muscle cells, or fibrous tissue (Figs. 3B, C, D, and 4A). Typical specimens of mucosa, having a surface area of 10-20 $\mathrm{cm}^{2}$ yielded 75-150 million cells. The percentage of cell yield of such a procedure is difficult to assess. Examination of fragments of lamina propria remaining after collagenase treatment revealed significant numbers of undissociated cells, probably at least equal in number to those isolated. The occurrence of the eosinophil in equivalent numbers in both the isolated population and in Wright's stained frozen sections of tissue suggested that gross cell selectivity had not occurred during isolation. Peripheral blood mononuclear cells subjected to the 

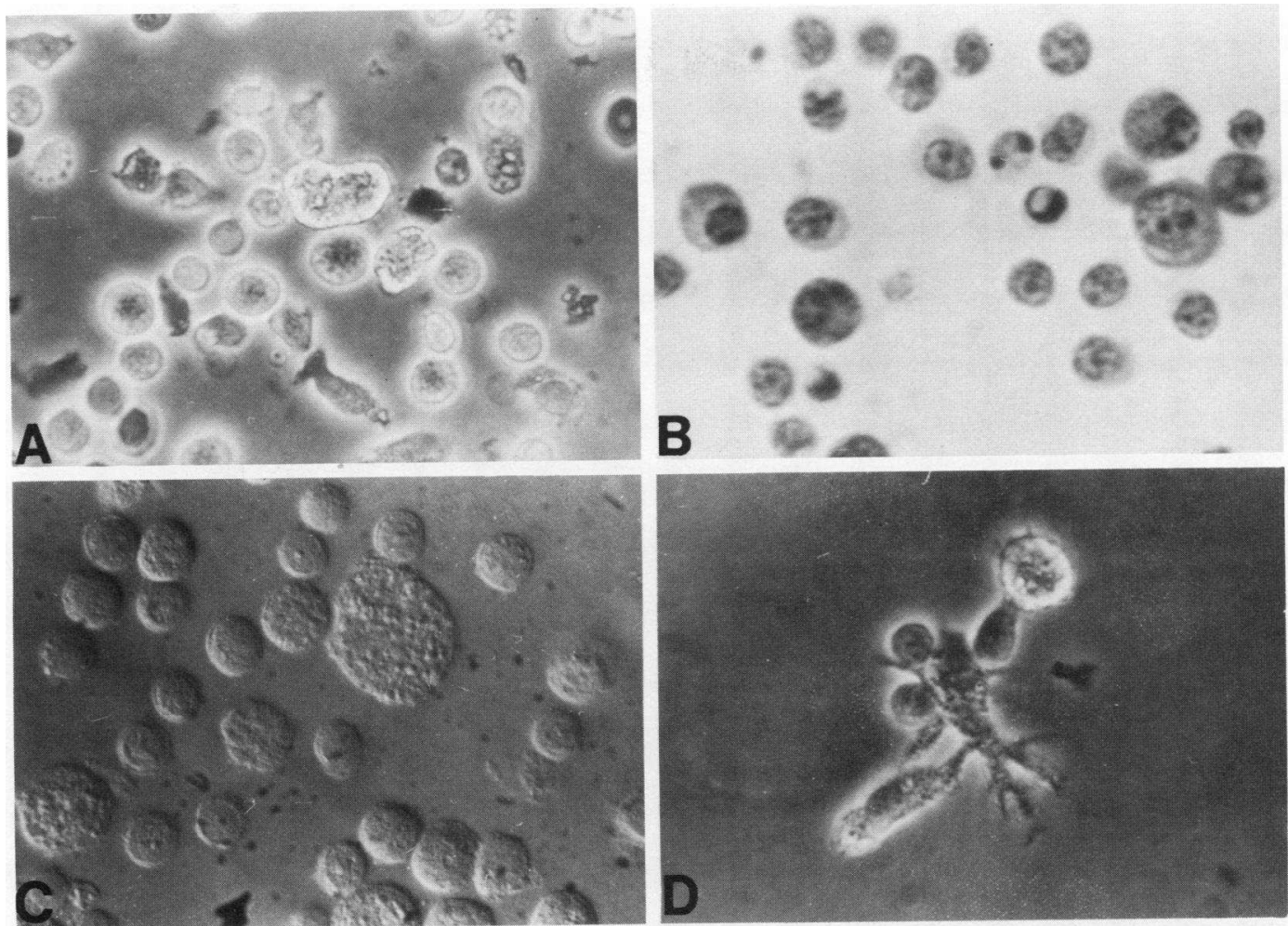

FIGURE 3 Appearance of isolated colonic lymphoid cells. (A) Crude colonic lamina proprial cell suspension after treatment with purified collagenase and before sedimentation over Ficoll-Hypaque. Note cell debris and occasional erythrocytes (phase contrast $\times 500)$. (B) Final colonic lymphoid cell preparation showing heterogeneity in size and nuclear-cytoplasmic ratio (Wright's stain $\times 1,000$ ). (C) Final colonic lymphoid cell preparation under differential interference contrast microscopy $(\times 1,000)$. (D) Final colonic lymphoid cell preparation showing lymphocyte-macrophage association (phase contrast $\times 500$ ).

same chemical treatments used in the isolation of in testinal cells were morphologically unchanged and remained $95 \%$ viable by trypan blue exclusion.

\section{Properties of intestinal lymphoid cells(Tables I and II)}

Lymphocyte morphology. The colonic lymphocytes, in comparison with those of peripheral blood, showed greater heterogeneity in size and nuclearcytoplasmic ratio, and more of the cells had basophilic cytoplasm and nucleoli. The colonic cell population also showed a greater degree of rosette-like association between lymphocytes and macrophages (Fig. 3D).

Membrane characteristics of intestinal lymphocytes. Erythrocyte (E) rosetting-, "activated" E-rosetting-, EAC-rosetting-, and membrane immunoglobulin-positive cells, as well as cells lacking the E-rosetting property and membrane Ig ("null" cells) are shown in Table I. T lymphocytes, as reflected by $18 \mathrm{~h}$ E rosetting, were present in numbers not significantly dif- ferent from peripheral blood. Activation rosettes (8), on the other hand (those formed promptly upon incubation with sheep erythrocytes, and felt to represent stimulated lymphoid cells) were present in significantly greater numbers in the intestinal mucosa. Cells forming rosettes with antibody and complement (EAC rosettes) were also significantly more numerous as were cells bearing intrinsic membrane immunoglobulin. Null cells, present as $7 \%$ of lymphocytes in peripheral blood, were conspicuously absent from the intestinal lymphoid cell population.

The distribution of individual membrane immunoglobulin chains is shown in Table II. Colonic lymphocyte populations showed marked increases in the proportion of cells bearing IgG, IgA, and IgE, whereas the proportions of cells bearing $\operatorname{IgM}$ and $\operatorname{IgD}$ were significantly diminished in comparison with peripheral blood. Proportions of cells bearing the $\kappa$ - and $\lambda$ classes of immunoglobulin light chains were similar in the two sites.

Lymphoblastic transformation (Table III). The proliferative responses of the intestinal cells to PHA

Human Intestinal Mucosal Lymphoid Cells 

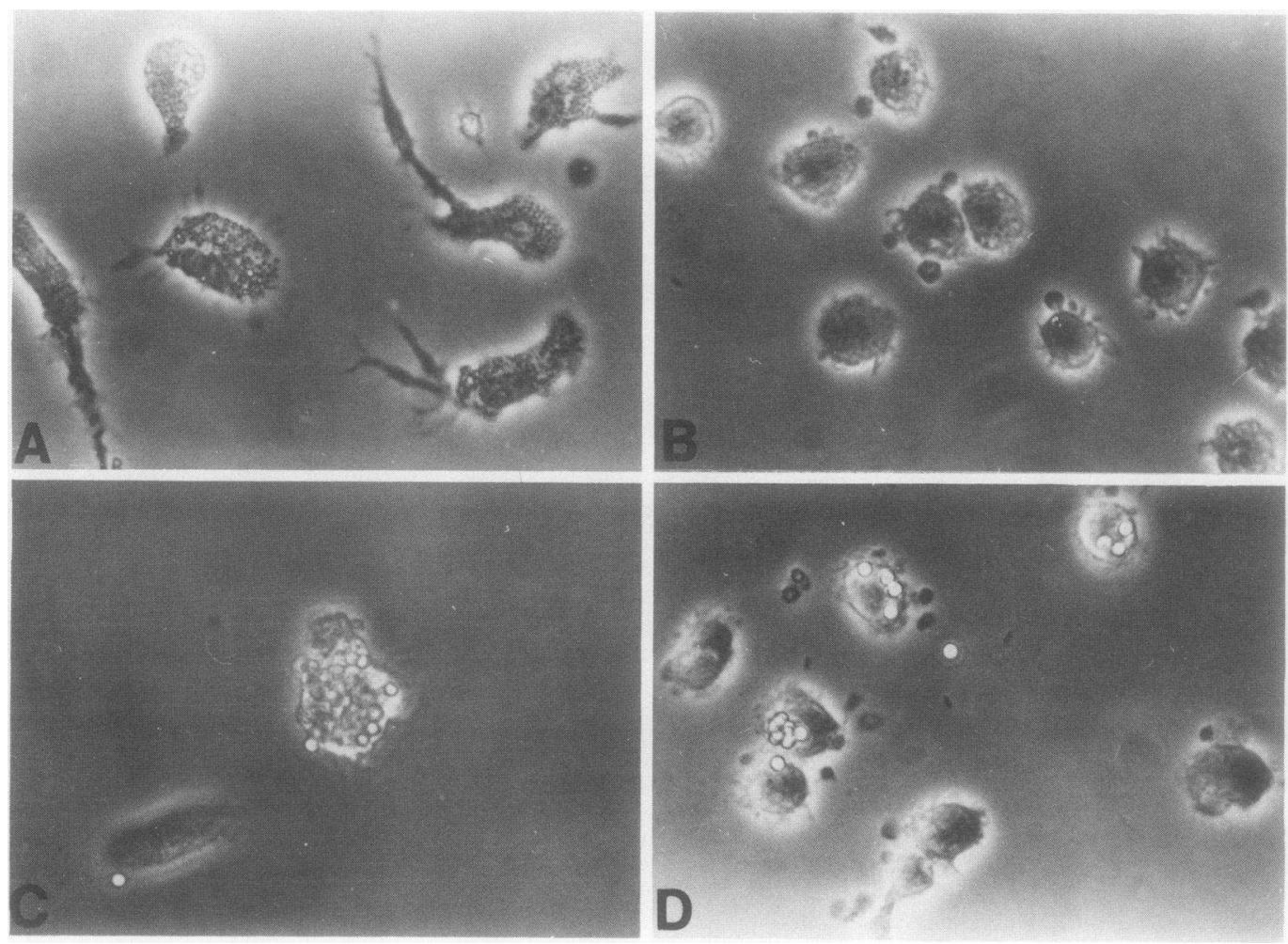

FIGURE 4 Comparative morphology of intestinal macrophages and peripheral blood monocytes. (A) Intestinal macrophage monolayer showing large size, marked granularity, and pseudopod formation (phase contrast $\times 500$ ). (B) Peripheral blood monocyte monolayer for comparison with (A) (phase contrast $\times 500$ ). (C) Intestinal macrophage containing large number of ingested latex particles (phase contrast $\times 500$ ). (D) Peripheral blood monocytes prepared as in (C), but containing fewer ingested latex particles (phase contrast $\times 500$ ).

and Con A confirmed the lymphoid nature of the populations and revealed yet another distinguishing feature with respect to circulating lymphocytes. PHAinduced stimulation of colon cells was less than that seen with Con $A$, and was also less than that induced by PHA in peripheral blood populations. Radioactive thymidine incorporation by unstimulated cultures of colonic mucosal and peripheral blood lymphoid cells was equal within a given experiment.

In vitro antibody synthesis (Fig. 5). As measured by incorporation of radioactive amino acids into protein precipitable with anti-immunoglobulin reagents, intestinal lymphoid cells showed approximately 35 times as much activity as did equal numbers of peripheral blood lymphoid cells. For the colon cell population, approximately one-third the counts precipitable by polyvalent anti-immunoglobulin antisera were precipitated by anti-IgA.

Macrophage-monocyte morphology (Table I, Fig. 4). Approximately $10 \%$ of intestinal mononuclear cells had the properties of macrophages (Fig. 4A), showing large size (14-25 $\mu \mathrm{m})$ rapid and sustained adherence to glass in the presence of serum (10), and numerous cytoplasmic granules of variable size. The monocytes of peripheral blood (Fig. 4B), by contrast, were smaller, devoid of cytoplasmic granules, were less active in spreading, and showed a high proportion of cells that later detached.

Macrophage-monocyte phagocytic activity (Figs. 4C and $D$ ). In comparing the adherent mononuclear cells of the two populations, a greater percentage of colonic cells were found to be phagocytic ( 80 vs. $60 \%$ ). In addition, the colonic macrophages demonstrated a greater phagocytic capacity as reflected in the maximum numbers of particles ingested ( 25 vs. 10).

\section{DISCUSSION}

Circulating lymphoid cells, because of their ready availability and relative ease of preparation, have been used almost exclusively in studies of the cellular immune system in man. However, to fully elucidate the nature of the local gastrointestinal immune system as well as to adequately study its role in states such as gastrointestinal cancer or inflammatory bowel disease, the characteristics of lymphoid cells that have 
become localized in the intestinal mucosa must be ascertained. The first step in the study of tissue lymphoid cells is their isolation in intact and viable form appropriate for establishment of in vitro culture systems. Therefore, a major objective of the present study was the development of a satisfactory isolation procedure. In addition, we have carried out comparative studies of the immunological reactivity of these cells and circulating lymphoid elements.

The isolation procedure described utilized the mucolytic agent DTT, EDTA, and calcium-magnesiumfree media as had been applied by others for the removal of epithelial cells from the small intestine (11). The lamina propria was dissociated in a solution of purified collagenase that possessed little additional proteolytic activity. There was no evidence of damage to the isolated cells, making possible the immediate establishment of in vitro experiments.

Morphologically, the presence in the intestinal population of cells with nucleoli and basophilic cytoplasm and of plasma cells, suggests that ribosome assembly, and immunoglobulin protein synthesis is proceeding at a greater rate than in circulating lymphocytes. The frequently observed cellular associations between intestinal lymphocytes and macrophages may be analogous to those observed by Lipsky and Rosenthal (12) among antigen-stimulated guinea pig cells, and may be a morphologic reflection of antigen processing.

Significant differences in membrane properties were also apparent between the two populations. Bone marrow-derived (B) lymphocytes, by the dual criteria of the presence of membrane immunoglobulin and EAC-rosette formation, were significantly increased. In part, this increase may have occurred at the expense of the null cell (E-rosette-negative, membrane immunoglobulin-negative) population, an idea consistent with emerging concepts of B-lymphocyte maturation. In this regard, others have shown that a considerable proportion of isolated null cells, upon in vitro culture, acquire membrane immunoglobulin and the capacity to synthesize and secrete antibody (13). Recent evidence (14) indicates that IgM and IgD are the major membrane immunoglobulins of peripheral blood lymphocytes and as such, represent the precursors of cells that will eventually synthesize and secrete IgG, IgA, and IgE. The presence in the colon of increased proportions of membrane IgG-, IgA-, and IgE-positive cells, many with plasma cell morphology, and the decreased proportions of cells bearing $\operatorname{IgM}$ and $\operatorname{IgD}$ supports the view that the intestinal B-lymphocyte population has undergone maturation. The single immunoglobulin class most prevalent in the membrane of intestinal lymphocytes was IgA, further emphasizing the specificity of IgA for the intestinal secretory immune system. As is apparent
TABLE I

Properties of Intestinal Mucosal and Circulating Lymphoid Cells*

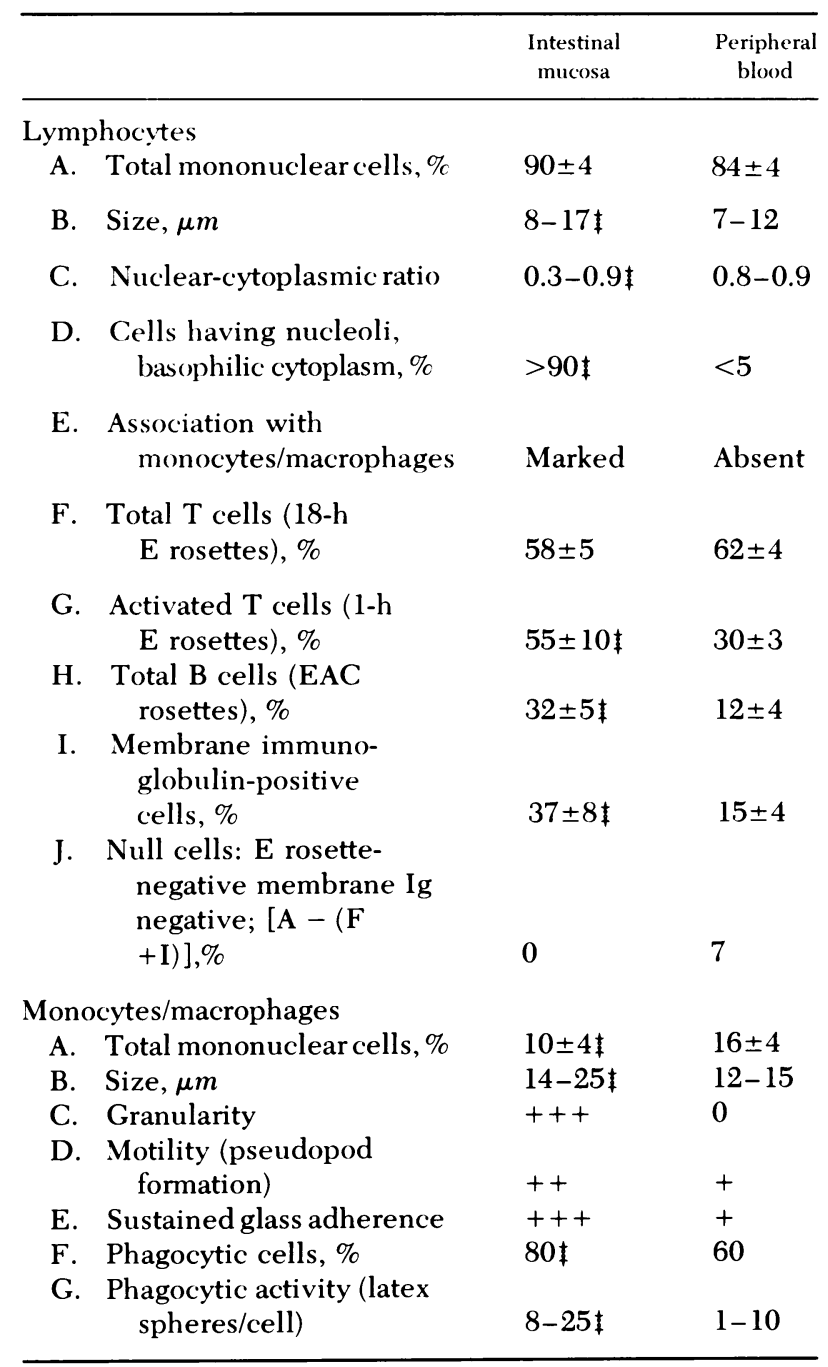

* All percentages are with reference to the total mononuclear cell population and are expressed as the mean $\pm 1 \mathrm{SD}$.

\$ Significantly different from peripheral blood at the 0.01 level.

from Table II, the sum of the percentages of cells having membrane immunoglobulin of the several classes studied exceeded that measured with a single polyvalent anti-immunoglobulin antisera or derived from the sum of the two antilight chain antisera. This overlap indicates that some intestinal lymphocytes possess more than one membrane immunoglobulin and thus are still undergoing a maturational process.

These data on the membrane immunoglobulin of viable suspensions of intestinal lymphocytes supplement existing data gathered solely from immuno- 
TABLE II

Membrane Immunoglobulin Distribution on Colonic Mucosal and Circulating Lymphoid Cells

\begin{tabular}{lccccc}
\hline & \multicolumn{2}{c}{ Colonic mucosal } & & \multicolumn{2}{c}{ Peripheral blood } \\
\cline { 2 - 3 } \cline { 5 - 6 } & $\begin{array}{c}\text { Total } \\
\text { mononuclear } \\
\text { cells }\end{array}$ & $\begin{array}{c}\text { Membrane } \\
\text { immunoglobulin- } \\
\text { positive cells }\end{array}$ & & $\begin{array}{c}\text { Total } \\
\text { mononuclear } \\
\text { cells }\end{array}$ & $\begin{array}{c}\text { Membrane } \\
\text { immunoglobulin- } \\
\text { positive cells }\end{array}$ \\
\hline & $\%$ & $\%$ & & $\%$ & $\%$ \\
Polyvalent & & & & & \\
immunoglobulin positive & $37 \pm 8$ & 100 & & $15 \pm 4$ & 100 \\
IgG & $10 \pm 4$ & 27 & & $<2$ & $<13$ \\
IgM & $13 \pm 6$ & 35 & & $12 \pm 3$ & 80 \\
IgD & $6 \pm 3$ & 16 & & $12 \pm 3$ & 80 \\
IgA & $26 \pm 4$ & 70 & & $<1$ & $<7$ \\
IgE & $6 \pm 3$ & 16 & & $<1$ & $<7$ \\
$\kappa$-light chain & $24 \pm 6$ & 65 & & $9 \pm 2$ & 60 \\
$\lambda$-light chain & $14 \pm 4$ & 38 & & $6 \pm 2$ & 40 \\
Sum of $\kappa$ and $\lambda$ & 38 & 101 & & 15 & 100 \\
\hline & & & & & \\
\hline
\end{tabular}

fluorescence studies of frozen tissue sections. Such studies are by nature semi-quantitative and reveal cytoplasmic rather than membrane immunoglobulin content. In preparing cells for immunofluorescence, strict attention was paid to the need for incubation and washing at $37^{\circ} \mathrm{C}$ to effectively remove any host cytophilic antibody. The presence of such antibody on Fc receptor-bearing cells can lead to a false-positive determination of membrane immunoglobulin $(4,5)$. The intrinsic membrane immunoglobulin of each lymphocyte contains only one of the two classes of light chains ( $\kappa$ and $\lambda$ ). Thus, the finding in the present study (Table II) that the sum of the cells positive with anti- $\kappa$ - and anti- $\lambda$-reagents equalled the number staining with polyvalent anti-immunoglobulin antisera having both anti- $\kappa$ - and anti- $\lambda$-activity is evidence that any cytophilic antibody (which would contain both types of light chain) had indeed been removed. Prevention of this artifact represents another advantage of suspensions of isolated cells over frozen tissue sections for immunological study.
Increased immunoglobulin production by intestinal cells could be predicted on the basis of these morphologic and membrane immunoglobulin observations. However, actual immunoglobulin synthesis was greater than that predicted purely on the basis of the increased number of $B$ lymphocytes in the intestinal site. Thus, the intestinal cells are indeed elaborating immunoglobulin protein at a greater rate than the cells of peripheral blood. Locally produced antibody makes a quantitatively important contribution to the circulating immunoglobulin pool (15), and functions within the secretory immune system to modulate the transmucosal passage of antigen (16). It may also participate in antibody-dependent cellular cytotoxicity (17), a reaction which seems to be particularly relevant to inflammatory bowel disease (18).

The divergent responses to Con A and PHA must reflect a basic difference between the two populations. Differential membrane binding of mitogen or actual differences in responsiveness are possible explanations. The fact that the two populations, when

TABLE III

Differential Responses to Lectin Stimulation of Intestinal Mucosal and Circulating Lymphoid Cells

\begin{tabular}{|c|c|c|c|c|c|c|c|c|}
\hline \multicolumn{5}{|c|}{$\begin{array}{l}{\left[{ }^{3} \mathrm{H}\right] \text {-Thymidine incorporation }} \\
\text { colonic mucosal lymphoid cells, cpm }\end{array}$} & \multicolumn{4}{|c|}{$\begin{array}{c}{\left[{ }^{3} \mathrm{H}\right] \text { Thymidine incorporation }} \\
\text { peripheral blood lymphoid cells, } c p m\end{array}$} \\
\hline Experiment & $\begin{array}{c}\text { Con A } \\
(50 \mu \mathrm{g} / \mathrm{ml})\end{array}$ & $\begin{array}{c}\text { PHA } \\
(0.1 \mathrm{ml} / \mathrm{ml})\end{array}$ & $\begin{array}{l}\text { Unstim- } \\
\text { ulated }\end{array}$ & $\begin{array}{l}\text { Con A:PHA } \\
\text { ratio }\end{array}$ & $\begin{array}{c}\text { Con A } \\
(50 \mu \mathrm{g} / \mathrm{ml})\end{array}$ & $\begin{array}{c}\text { PHA } \\
(0.1 \mathrm{ml} / \mathrm{ml})\end{array}$ & $\begin{array}{l}\text { Unstim- } \\
\text { ulated }\end{array}$ & $\begin{array}{l}\text { Con A:PHA } \\
\text { ratio }\end{array}$ \\
\hline 1 & 5,848 & 2,101 & 112 & 2.8 & 123 & 1,404 & 105 & 0.09 \\
\hline 2 & 2,695 & 2,502 & 633 & 1.1 & 1,448 & 19,935 & 647 & 0.07 \\
\hline 3 & 18,557 & 5,205 & 489 & 3.6 & 33,848 & 43,144 & 537 & 0.78 \\
\hline 4 & 14,940 & 970 & 384 & 15.4 & 16,090 & 25,770 & 329 & 0.62 \\
\hline 5 & 2,924 & 1,057 & 33 & 2.8 & 6,180 & 17,573 & 31 & 0.35 \\
\hline 6 & 16,096 & 7,368 & 695 & 2.2 & 385 & 27,725 & 513 & 0.01 \\
\hline
\end{tabular}


unstimulated, incorporated similar amounts of radiothymidine, suggests that the isolation procedure employed did not have a stimulatory effect.

The opportunity to harvest the intestinal fixed macrophage population permits new approaches to the study of this cell in intestinal immunopathology. In addition to its cooperative immune interaction with the several classes of lymphocyte $(19,20)$, the macrophage has been shown to be selectively cytotoxic for cancer cells (21). Isolated macrophages of the intestinal mucosa showed increased size, granularity, spreading, sustained adherence, and phagocytic activity, which taken together reflect a state of activation (22) or maturation. Macrophage activation largely involves responses to the products of stimulated lymphocytes $(19,22)$, and the intimate association of the two cell types in the lamina propria is consistent with such a mechanism.

The intestinal cell populations also contained up to $3 \%$ eosinophilic leukocytes. The eosinophil's chemotactic response to antigen-antibody complexes, selective phagocytosis of these complexes, and ability to modulate the action of histamine (23), all reflect a responsiveness to immune events in the tissues. Their presence suggests that mucosal lymphoid cells are actively responding to the local antigenic milieu that includes intestinal bacteria and their products. As an interface with the environment, and as a site of involvement with malignancy and autoimmune processes, the colon is a site of heightened immune activity. In addition, a break in the mucosal barrier from any cause would permit increased access of antigen to these activated lymphoid cells, thereby setting the stage for self-perpetuating immunologically mediated cell damage.

The intestinal lymphocyte/macrophage population may undergo the related processes of activation and maturation within the intestinal mucosa. In addition, cells that have undergone these changes elsewhere may preferentially "home" (24) on the intestinal site. McWilliams, et al., ${ }^{2}$ after separation and reinfusion of mouse lymph node cells, present evidence that the acquisition of membrane IgA is a stimulus for the lymphocyte to home on the intestinal mucosa. Rudzik et al. (25), in transfer experiments with rabbit Peyer's patch lymphocytes, find that IgA-containing cells repopulated the lamina propria of both the gut and bronchial tree. These authors suggest that antigenic stimulation in one site results in a common distribution of antibody-forming cells to other mucosal sites. Based on animal studies, it is felt that cells of the lamina propria are derived from immunoblasts, particularly of the B series, that entered the tissue from the circulation $(24,26)$, in contrast to the "gut-associated lymphoid

${ }^{2}$ McWilliams, M., J. Phillips-Quagliata, and M. E. Lamm. 1977. Mesenteric lymph node B lymphoblasts which home to the small intestine are precommitted to IgA synthesis. J. Exp. Med. 145: 866-875.

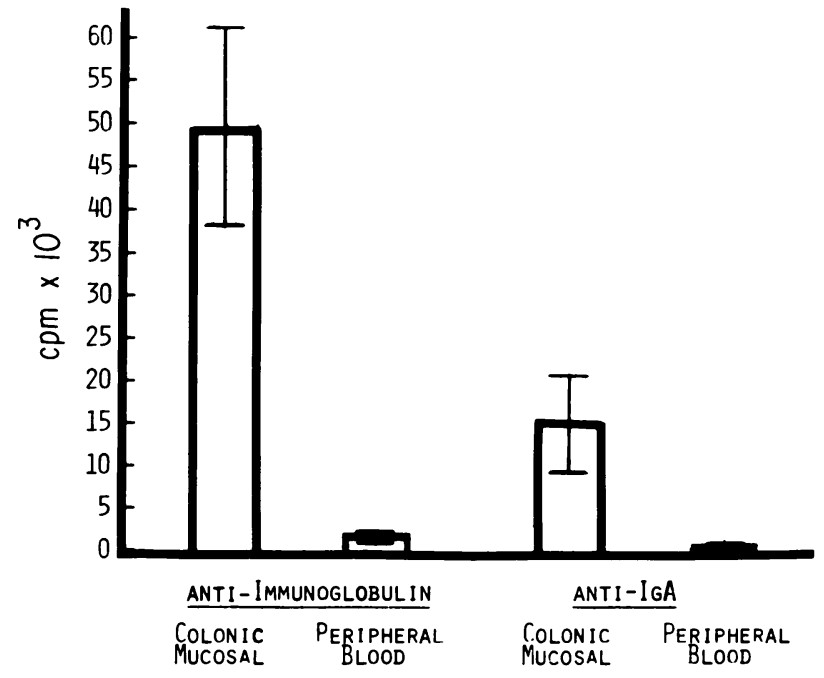

FiguRE 5 Incorporation of ${ }^{14} \mathrm{C}$-amino acids into immunoglobulin protein by intestinal and peripheral blood lymphoid cells. cpm, counts precipitated with a combination of goat antihuman immunoglobulin or goat anti-human IgA and rabbit anti-goat gamma globulin minus counts nonspecifically precipiated with normal goat serum and rabbit anti-goat gamma globulin.

tissues" (Peyer's patches and appendix) which come to be populated by small unstimulated lymphocytes. The immunoblasts, after undergoing antigenic stimulation in sites such as mesenteric lymph nodes, enter the thoracic duct and general circulation to home on the intestinal lamina propria.

Studies of the functional immune reactivity of isolated intestinal lymphoid cells have been few in number. Rudzik and Bienenstock (27) and Rudzik et al. (28) have used physical, nonenzymatic means of separating rabbit small intestinal lymphoid cells for study of tissue lymphocyte sub-populations. These rabbit small intestinal lymphoid cells were remarkably rich in null cells which bore neither a thymic antigen marker nor membrane immunoglobulin, a divergent finding from our present observations in human colonic tissue.

The use of intestinal lymphoid cells in suspension should allow further examination of the possibility that ulcerative colitis, regional enteritis, and glutensensitive enteropathy may result from misdirected local immune events initiated by intestinal antigens. Clancy (29) has recently reported the isolation by physical means of lymphocytes from human small intestine involved with regional enteritis. The cells were larger in size and exhibited higher rates of DNA synthesis than did control mucosal lymphocytes. In attempting to apply physical means, such as those employed by Clancy (29), to the separation of human colonic lymphoid cells, we have encountered mucusinduced clumping, poor viability, and low cell yield, all of which limited attempts at characterization. 
Preliminary results indicate that the sequential method of lymphoid cell isolation as described can also be applied to surgical samples of human small intestine with favorable results.

The induction and mediation of immune responses is characterized by a variety of complex cellular interactions. Effective study of tissue-based phenomena such as suppressor and helper cell function, lymphokine production and action, cytotoxic reactions, and the maturation, activation, and homing of immunocompetent cells demands that the cells involved be experimentally manipulated. The availability of isolated populations of intestinal lymphoid cells should prove of value in furthering the understanding of these immune events.

\section{ACKNOWLEDGMENTS}

This research was supported by a grant from the National Foundation for Ileitis and Colitis, Inc., New York.

\section{REFERENCES}

1. Strom, T. B., N. L. Tilney, C. B. Carpenter, and G. J. Busch. 1975. Identity and cytotoxic capacity of cells infiltrating renal allografts. N. Engl. J. Med. 292: 12571263.

2. Mavligit, G. M., A. V. Jubert, J. U. Gutterman, C. M. McBride, and E. M. Hersh. 1974. Immune reactivity of lymphoid tissues adjacent to carcinoma of the ascending colon. Surg. Gynecol. Obst. 139: 409-412.

3. Böyum, A. 1968. Isolation of mononuclear cells and granulocytes from human blood. Isolation of mononuclear cells by one centrifugation, and of granulyctes by combining centrifugation and sedimentation at lg. Scand. J. Clin. Lab. Invest. 21 (Suppl. 97): 77-89.

4. Lobo, P., F. B. Westervelt, and D. A. Horowitz. 1975. Identification of two populations of immunoglobulinbearing lymphocytes in man. J. Immunol. 114: 116-119.

5. Kumagai, K., T. Abo, T. Sekizawa, and M. Sasaki. 1975. Studies of surface immunoglobulins on human B lymphocytes. I. Dissociation of cell-bound immunoglobulins with acid $\mathrm{pH}$ or at $37^{\circ} \mathrm{C}$. J. Immunol. 115: $982-$ 987.

6. Pernis, B., L. Forni, and L. Amante. 1971. Immunoglobulins as cell receptors. Ann. N. Y. Acad. Sci. 190: $420-431$.

7. Jondal, M., G. Holm, and H. Wigzell. 1972. Surface markers on human $\mathrm{T}$ and $\mathrm{B}$ lymphocytes. I. A large population of lymphocytes forming nonimmune rosettes with sheep red blood cells. J. Exp. Med. 136: 207-215.

8. Wybran, J., and H. H. Fudenberg. 1973. Thymusderived rosette-forming cells in various human disease states: cancer, lymphoma, bacterial and viral infections, and other diseases. J. Clin. Invest. 52: 1026-1032.

9. Ehlenberger, A. G., M. McWilliams, J. M. PhillipsQuagliata, M. E. Lamm, and V. Nussenzweig. 1976. Immunoglobulin-bearing and complment-receptor lymphocytes constitute the same population in human peripheral blood. J. Clin. Invest. 57: 53-56.

10. Koller, C. A., G. W. King, P. E. Hurtubise, A. L. Sagone, and A. F. LoBuglio. 1973. Characterization of glass adherent human mononuclear cells. J. Immunol. 111 : 1610-1612.
11. Stern, B. K., and W. E. Jensen. 1966. Active transport of glucose by suspensions of isolated rat intestinal epithelial cells. Nature (Lond.). 209: 789-790.

12. Lipsky, P. E., and A. S. Rosenthal. 1975. Macrophagelymphocyte interaction. II. Antigen-mediated interactions between immune guinea pig lymph node lymphocytes and syngeneic macrophages. J. Exp. Med. 141: 138-154.

13. Chess, L., H. Levine, R. P. MacDermott, and S. F. Schlossman. 1975. Immunologic functions of isolated human lymphocyte subpopulations. VI. Further characterization of the surface Ig negative, $\mathrm{E}$ rosette negative (null cell) subset. J. Immunol. 115: 1483-1487.

14. Vitetta, E. S., and J. W. Uhr. 1975. Immunoglobulin receptors revisited. Science (Wash. D. C.). 189: 964-969.

15. Bull, D. M., J. Bienenstock, and T. B. Tomasi, Jr. 1971. Studies on human intestinal immunoglobulin A. Gastroenterology. 60: 370-380.

16. Walker, W. A., and K. J. Isselbacher. 1974. Uptake and transport of macromolecules by the intestine. Possible role in clinical disorders. Gastroenterology. 67: 531-550.

17. MacLennan, I. C. M., G. Loewi, and A. Howard. 1969. A human serum immunoglobulin with specificity for certain homologous target cells, which induces target cell damage by normal human lymphocytes. Immunology. 17: 897-910.

18. Stobo, J. D., T. B. Tomasi, K. A. Huizenga, R. J. Spencer, and R. G. Shorter. 1976. In vitro studies of inflammatory bowel disease. Surface receptors of the mononuclear cell required to lyse allogeneic colonic epithelial cells. Gastroenterology. 70: 171-176.

19. David, J. R. 1975. Macrophage activation by lymphocyte mediators. Fed. Proc. 34: 1730-1736.

20. Unanue, E. R., and J. Calderon. 1975. Evaluation of the role of macrophages in immune induction. Fed. Proc. 34: 1737-1742.

21. Piessens, W. F., W. H. Churchill, Jr., and J. R. David. 1975. Macrophages activated in vitro with lymphocyte mediators kill neoplastic but not normal cells. J. Immunol. 114: 293-299.

22. Mooney, J. J., and B. H. Waksman. 1970. Activation of normal rabbit macrophage monolayers by supernatants of antigen-stimulated lymphocytes. J. Immunol. 105: $1138-1145$.

23. Cline, M. J. 1975. The White Cell. Harvard University Press, Cambridge, Mass. 111-114.

24. Gowans, J. L., and E. J. Knight. 1964. The route of recirculation of lymphocytes in the rat. Proc. R. Soc. Lond. B. Biol. Sci. 159: 257-282.

25. Rudzik, R., R. L. Clancy, D. Y. E. Perey, R. P. Day, and J. Bienenstock. 1975. Repopulation with IgA-containing cells of bronchial and intestinal lamina propria after transfer of homologous Peyer's patch and bronchial lymphocytes. J. Immunol. 114: 1599-1604.

26. Parrott, D. M. V., and A. Ferguson. 1974. Selective migration of lymphocytes within the mouse small intestine. Immunology. 26: 571-588.

27. Rudzik, O., and J. Bienenstock. 1974. Isolation and characteristics of gut mucosal lymphocytes. Lab. Invest. 30: 260 266.

28. Rudzik, O., R. L. Clancy, D. Y. E. Perey, J. Bienenstock, and D. P. Singal. 1975. The distribution of a rabbit thymic antigen and membrane immunoglobulins in lymphoid tissue, with special reference to mucosal lymphocytes. J. Immunol. 114: 1-4.

29. Clancy, R. 1976. Isolation and kinetic characteristics of mucosal lymphocytes in Crohn's disease. Gastroenterology. 70: 177-180. 